\title{
ETT NYTT FORSKNINGSOMRÅDE
}

\section{Maths Isacson}

Under de senaste två årtiondena har det skett en attitydförändring bland Sveriges kulturmiljövårdare i deras syn på äldre industrimiljöer. Betydande insatser görs idag för att restaurera, skydda och återanvända äldre industrianläggningar. Nyorienteringen reser en rad frägor: hur gick det till när industrins miljöer och minnen blev en accepterad del av kulturarvet, och vad har - har inte accepterats som kulturarv under olika perioder? Vilka stretade emot och vilka gick i bräschen? Hur argumenterade olika aktörer? Vad är format i den nationella och lokala kontexten? Vad är hämtat frän utlandet?

Frågorna är mainga och forskningen befinner sig ännu i sin linda. En intressant vetenskaplig studie presenterades våren 1996 vid Tema teknik och social förändring vid Linköpings universitet. Då disputerade Annika Alzén på en avhandling med titeln "Fabriken som kulturarv», utarbetad inom forskningsprojektet Modernisering och kulturarv. $^{1}$

Alzén har studerat attitydskiftet utifrån exemplet Norrköping och det område som numera allmänt går under namnet Norrköpings industrilandskap, eller kort och gott Industrilandskapet. I avhandlingen skildrar hon hur ett äldre synsätt under perioden från slutet av 1960-talet ersattes av ett nytt, som inkluderade industrins nedlagda produktions- och förrådsbyggnader. Hennes ambition är att «följa hur inställningen till fabriksområdet förändrades i riktning mot ett industrilandskap". Det konkreta bevarandet och enskilda byggnaders restaurering ligger däremot utanför undersökningen.

Diskurs är ett nyckelbegrepp i avhandlingen. Med diskurs avser Alzén «åsiktslinjer eller normer för det accepterade tän- kandet», dvs det gemensamma tankemönstret uttryckt i handling, samtal och texter.

Utifrån exemplet Norrköping beskriver och analyserar hon hur en äldre etablerad kulturarvsdiskurs, som hade föga till övers för industrianläggningar, under loppet av ett drygt årtionde fick ge vika för en ny diskurs, som inte bara accepterade utan även betonade att äldre fabriker och andra industribyggnader skulle bevaras. Hennes uppgift blir att kartlägga de hämmande respektive pådrivande faktorerna i detta perspektivskifte, peka ut aktörerna, lyfta fram deras argument och ringa in viktiga händelser och processer lokalt och nationellt.

Alzén menar att det etablerade kulturar- 
$98 v e t^{2}$ är en "socialt konstruerad företeelse», något som skapas av människor genom avskiljning, kulturell "frysning" och inrättandet av särskilda institutioner med uppgift att hantera det framtida bevarandet. Hon skiljer på två olika sätta att bevara ett kulturarv, dels att reservera samt dels att kultivera. Det första syftar till att skydda mot förändring, medan det senare tillåter att kulturarvet brukas och förändras. Hon frågar sig hur det gick till när industrin legitimerades som ett kulturarv och vilka tankemönster som dominerade under olika tider.

Den traditionella antikvariska kulturarvsdiskursen betonade ålder, formgivning, historiskt innehåll och sällsynthet. I denna diskurs framhölls det autentiska, det ursprungliga och äkta. Den hade en förkärlek för enskilda föremål och byggnader. Den nya moderna kulturarvsdiskursen lägger istället tonvikt vid miljöer, vid helheten, sociala sammanhang, det vardagliga och vid förändring.

I min genomgång av Alzéns avhandling ger jag först en utförlig presentation av innehållet i boken. Därefter övergår jag till en utvärdering och kritisk granskning av begrepp, metod och tolkning.

\section{ETT FÄLT ETABLERAS}

Den traditionella kulturarvsdiskursen företräddes av antikvarier och personer i hembygdsrörelsen. För dem var industri och kultur varandras motsatser. Bergshan-

\section{FABRIKEN SOM KULTURARV}

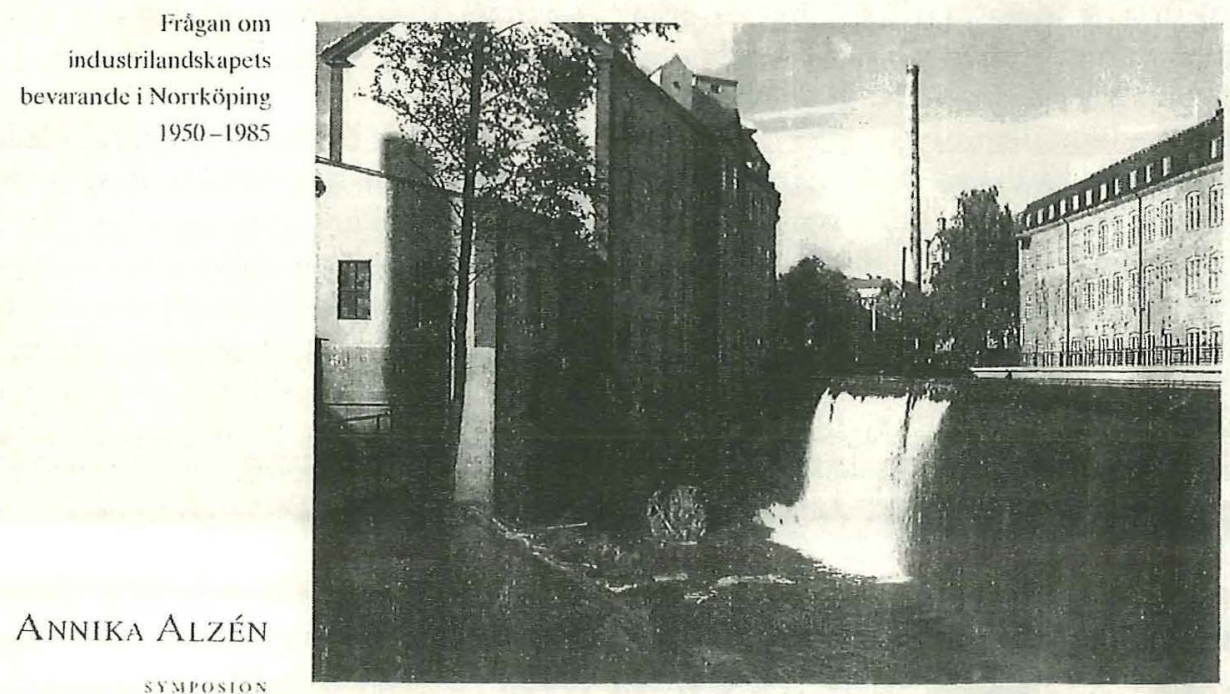


teringens äldre miljöer var dock redan omkring 1900 föremål för bevarandeinsatser. Avesta Jernverk, Stora Kopparbergs Bergslag och Laxå bruk var tidiga att skydda byggnader och etablera små industrimuseer. Ar 1924 startade Tekniska museet i Stockholm med Carl Sahlin och Torsten Althin som förgrundsgestalter. På museets initiativ uppmärksammades äldre teknikhistoriska minnesmärken runt om i landet, i första hand miljöer som ansågs representativa för den tidigindustriella svenska järnhanteringen. Även unika föremål uppmärksammades. Intresset för detta var mest utbrett i Bergslagen. Hembygdsföreningar och antikvarier var annars upptagna med att rädda resterna av det utdöende bondesamhället.

Utestängningen av industrins artefakter från kulturarvet har flera förklaringar. Vid sidan av ekonomiska och praktiska svårigheter att bevara enskilda fabriker och hela industriområden pekar Alzén på fyra faktorer: 1) industri och kultur sågs som varandras motsatser, 2) industrin representerade det moderna samhället och ett bevarande ansågs framstegsfientligt, 3) industrins kvarlevor stod för armod, förnedring och elände, samt 4) medan industrin kännetecknades av förändring symboliserade kulturarvet äkthet och beständighet.

Från början av 1950-talet började röster höjas för att även industrisamhällets kvarlevor borde beaktas. Omsvängningen skedde först i England, där den hotade äldre industriarkitekturen gav bränsle till en industriarkeologisk rörelse. Dess företrädare, professionella liksom amatörer, ägnade sig till en början åt kvarlevor från det industriella genombrottet, åt unika maskiner och monumentala byggnader. På sikt uppmärksammades även miljöer, landskap och sociala dimensioner. ${ }^{3}$

I slutet av 1960-talet, i en tid när de första sprickorna i industrisamhällets fasad kunde anas, vaknade även i Sverige intresset för det industriella arvet. Perspektivet var här från allra första början bredare än i England. Inte bara historiskt intressanta byggnader utan även hela miljöer med enkla, föga monumentala, byggnader, liksom sociala förhållanden borde, hävdade de svenska pionjärerna (Marie Nisser, Gunnar Sillén m.fl.), bevaras. Tidsperspektivet behövde också vidgas och alla industribranscher inkluderas.

Från en försiktig början där antikvarierna höll sig avvaktande, växte från mitten av 1970-talet snabbt intresset. Det industriella arvet accepterades som en del av kulturarvet. Kulturavsdiskursen utvidgades, hävdar Alzén. Alltjämt lades dock stor vikt vid äkthet, sällsynthet och form.

I mitten av 1970-talet gick västvärlden in i en djup ekonomisk kris. I Sverige, liksom i andra industriländer, slog äldre fabriker igen. Samhällen som var helt beroende av en bransch, och inte sällan av ett enda företag, skakades i grunden. Arbetslöshet och avfolkning slog hårt mot en rad industrisamhällen, framförallt i Bergslagen och i mellersta Norrlands inoch kustland. I spåren av detta föddes ett folkligt intresse för industrisamhällets historia. Detta intresse, som går under samlingsnamnet «gräv-där-du-står-rörelsen» (grävrörelsen), blev en massrörelse som, menar Alzén, påverkade innehållet $\mathrm{i}$ den nya kulturarvsdiskursen och påskyndade dess etablering. Grävrörelsen påverkade också direkt händelseförloppet i Norrköping.

Ar 1974 fick Sverige en samlad och offensiv kulturpolitik, uttryckt i åtta kul- 
100 turpolitiska mål. Ett var bevarandemålet. Staten tog på sig ansvaret för hela samhällets historia. Den borgerliga samlingsregering som 1976 avlöste SAP förändrade inte politiken, däremot gav regeringsskiftet ytterligare bränsle till det växande folkliga intresset för industrisamhällets, arbetarklassens och arbetarrörelsens historia.

Från mitten av 1970-talet och tio år framåt skedde, hävdar Alzén, en övergång från en utvidgad till en modern kulturarvsdiskurs, en diskurs som framhöll vikten av att bevara industrisamhällets minnesmärken, men som också lade vikt vid sociala förhållanden, inklusive missförhållanden, arbetet, facklig och politisk verksamhet och arbetarkulturen.

\section{ETT FABRIKSOMRADE BLIR ETT INDUSTRILANDSKAP VÄRT ATT BEVARA}

I Norrköping växte problemen i början av 1970-talet. Holmens Bruk drev fortfarande pappersbruket i stadens centrum, men driften i textilfabrikerna hade upphört. Vad skulle kommunen göra med den äldre industrimiljön vid Motala ström, med alla tomma nedgångna lokaler från textilindustrins glansdagar? Under 1960-talet hade stadens centrala delar genomgått en hård sanering. Äldre bostäder och affärer revs och ersattes med ny bebyggelse. Enskilda personer och kulturhistoriska grupper hade ställt krav på att staden skulle bevara vissa kulturhistoriskt intressanta äldre byggnader. Ett bebyggelsereservat diskuterades.

Under 1950- och 1960-talen var den officiella inställningen att Norrköpingsborna på något sätt borde kompenseras för det fula fabriksområdet vid Strömmen.
Den traditionella kulturarvsdskursen var ännu stark och dess lokala företrädare hade föga till övers för industrin vid Strömmen. Inte ens rivningen av Norrköpings Bomullsväveri (Tuppen) i kvarteret Kullen, hösten 1969 väckte protester i staden.

Vid denna tid hade personer utifrån redan uppmärksammat Norrköpings äldre industriområde. Göran Lindahl, professor vid Konsthögskolans arkitekturskola i Stockholm, och Marie Nisser, då konsthistoriker i Uppsala, påtalade i flera artiklar omkring 1970 industriområdets unika karaktär. Båda hävdade att få städer i Europa kunde "uppvisa ett så förtätat och storslaget industrilandskap från storindustrins grundningsskede».

Uppmärksamheten resulterade i en motion till stadsfullmäktige i maj 1969, skriven av två moderata ledamöter. Motionärerna efterlyste ett handlingsprogram för kommunen i kulturmiljöfrågor. En ny utredning tillsattes, den s.k. Kulturmiljöutredningen. Den avgav sitt betänkande Miljöer och hus i Norrköpings innerstad i december 1973 och blev kommunens officiella ställningstagande när det gällde bevarande och förnyelse av Norrköpings innerstad. Den förenar, som Alzén påpekar, både ett nytänkande och ett traditionellt synsätt. Nytt var att industrimiljöerna vid Motala ström urskiljdes som en sammanhållen miljö värd att bevara. Samtidigt hävdades traditionella kriterier som ålder, formgivning, historiskt innehåll, sällsynthet m.m. Men, skriver Alzén, en «ny kulturarvsdiskurs anas». 


\section{ETABLERING AV EN NY KULTURARVSDISKURS}

Under de år som följde avskildes fabriksområdet vid Strömmen och kodades om till ett Industrilandskap med stort kulturhistoriskt värde. En ny utredning tillsattes 1979 och presenterade ett förslag som tydligt visar på klyftan mellan antikvarier och stadsplanerare. De förra betonade helheten och den historiska kontinuiteten. Stadsplanerarna och arkitekterna framhöll det visuella och estetiska. Det senare perspektivet blev också utredningens.

I slutet av 1970-talet hade den traditionella kulturarvsdiskursen ersatts av en utvidgad, som mer betonade helhet och förändring. Byggnadernas ålder, form och estetiska värden var dock kriterier som stadsplanerare och arkitekter gärna betonade. Industriområdet var dessutom experternas arbetsfält. Bevarandefrågan var inte folkligt förankrad. För detta krävdes en mångårig strid kring Holmens Bruks nya kraftverk. Den mer än tio år långa striden om kraftverket, där framförallt antikvarierna och stadens båda tidningar engagerade sig, väckte opinionen för industrilandskapet och dess bevarande. Fortfarande var det byggnaderna och det yttre som avsågs. Åsiktslinjen var industrihistorisk, men en alternativ diskurs började ta form. Den bidrog med nytt bränsle i debatten och till brottet med den traditionella diskursen.

\section{NYTT PERSPEKTIV OCH NYA ARGUMENT}

Fram till ungefär mitten av 1970-talet hade i första hand professionella grupper på riksplanet och i Norrköpings kommun agerat för att rädda Norrköpings industrilandskap. Från mitten av årtiondet kom nya aktörer in i bilden, samtidigt försköts perspektivet från industribyggnaderna och tekniken till arbetet och arbetarnas historia.

Flera skäl förklarar perspektivförskjutningen. Alzén betonar särskilt den politiska radikaliseringen från slutet av 1960talet, den djupa lågkonjunkturen efter årtionden av tillväxt och medföljande nedläggning av gamla fabriker, regeringsskiftet 1976, den nya kulturpolitiken, satsningen på studiecirklar inriktade på industrisamhällets historia samt radikala författares och konstnärers skildringar av arbetarklassens villkor. Den industrihistoriskt inriktade nya kulturarvsdiskursen utmanades från slutet av 1970-talet av en arbetarhistorisk och politiskt radikal diskurs.

Grävrörelsens bärande idé var att arbetarna själva skulle utforska historien, inte yrkesforskarna och antikvarierna. Det övergripande målet var en förändring av samhället. Historien sågs som en förändrande kraft. Att bevara arbetets och arbetarnas historia var ett verktyg i kampen för ett återtagande av den politiska makten.

Grävrörelsen stagnerade några år in på 1980-talet. ${ }^{4}$ Forskningen nådde i regel aldrig längre än till det tidiga industrisamhället och resultaten kunde inte föras samman med det fackliga-politiska arbetet i samtiden. De radikala idéerna kunde inte förverkligas och historien blev inte den förlösande kraft som många hoppats och trott. Däremot fick grävrörelsen betydelse för kulturarvsdiskursen. Nya kriterier skapades för vad som skulle räknas som kulturarv. Arbetet och arbetarnas historia ställdes i centrum för intresset. Samhällsfrågor liksom enkla, vardagliga, föga 
102 unika och vackra byggnader och föremål skulle beaktas, och detta i ett förändringsperspektiv.

\section{ARBETETS MUSEUM}

För Norrköping och dess industrilandskap avsatte grävrörelsen och dess idéer ett tydligt avtryck. Arbetets museum föddes ur denna rörelse. Visserligen tog det många år och åtskilliga turer innan museet i december 1991 kunde öppna sina utställningar i den moderniserade och förvandlade byggnaden på Laxholmen, mitt i Motala ström, men museet hämtar sin inspiration ur det landsomfattande folkliga intresset för arbetets och arbetarrörelsens historia. Den museala formen användes, menar Alzén, här för första gången av arbetarrörelsen och radikala debattörer för att bryta den borgerliga makten över kulturarvet.

Alzén skildrar ingående tillblivelseprocessen från våren 1977 fram till mitten av 1980-talet, från idén om ett arbetarrörelsens museum, via arbetarnas museum till Stiftelsen Arbetets museum. Hennes avsikt är att visa «på de samband som finns mellan Arbetets museum, Grävrörelsen och Industrilandskapet i Norrköping».

En byggnad var hela tiden vikt för det nya museet, Strykjärnet på Laxholmen i Motala ström. Uppslutningen var stor kring idén att utnyttja Strykjärnet för det nya museet. Stadsmuseet, som skulle skildra Norrköpings industrihistoria, placerades på andra sidan bron i kvarteret Bergsbron. När Bengt Göransson, statsråd med ansvar för kultur- och mediafrågor (ej utbildningsminister, som påstås s. 104) motiverade regeringens anslag till museet $\mathrm{i}$ 1983/84 års budgetproposition hade han två skäl: det stora intresset för arbetarhistoria samt att lokaliseringen av museet i Strykjärnet var ett bidrag till industrilandskapets bevarande. Alzén ser detta som en satsning från statens sida på «industriminnesvård i allmänhet».

\section{DEN NYA UTVIDGADE DISKURSENS TVA MOTSTRIDIGA RIKTNINGAR}

I mitten av 1980-talet hade det traditionella tankemönstret fått ge vika för en modern diskurs med två skilda inriktningar, en industrihistorisk och en arbetarhistorisk. I tiden låg den industrihistoriska något före, men båda bidrog till avvecklingen av den traditionella kulturarvsdiskursen. På flera punkter skiljer de sig åt, men de har en gemensam kärna $\mathrm{i}$ industrialismens historia. Den industrihistoriska diskursen såg kulturarvet ur ett «skattkammarperspektiv». Intresset riktades mot de enskilda föremålen, lämningarna och spåren av det förflutna. Den arbetarhistoriska diskursen såg däremot kulturarvet som en «förbindelseväv». De kommunikativa och kontinuitetsbevarande aspekterna betonades.

Ideologiskt befann sig de två riktningarna på kollisionskurs. Den springande punkten var vilka som hade rätt till det industriella arvet, arbetarna eller industriägarna. Motsättningen gällde dessutom synen på bevarandet. Mot en strikt vetenskaplig syn som framhöll byggnader, föremål och äktheten stod ett synsätt som lyfte fram sociala aspekter och människans skapande roll i förändringen.

Alzén ser Arbetets museum som en kompromiss mellan den industrihistoriska och arbetarhistoriska synen. Hon förklarar dock inte närmare hur denna kompromiss 
avspeglas i museets verksamhet, eller hur den kan avläsas i kulturarvsdiskursen.

\section{TVA TIDER OCH TVA RÖRELSER FÖR BEVARANDE AV KULTURARVET}

Var grävrörelsen det sena industrisamhällets motsvarighet till hembygdsrörelsen i industrisamhällets barndom, frågar Alzén i det sista kapitlet före sammanfattningen. Båda rörelserna uppstod i tider av genomgripande samhällsförändringar. Hembygdsrörelsen och de första museerna ville bevara resterna av allmogesamhället i en tid då industrialismen bröt in med full kraft. Men rörelsens företrädare ville inte bara bevara föreställningen om det goda livet i protest mot industrisamhällets otrygghet, utan hembygdsrörelsen blev en förmedlande länk mellan det agrara och det industriella samhället. Det gamla behövdes i skapandet av det nya. Gemeinschaft var inte möjligt utan Gesellschaft. ${ }^{5}$

Hämtade grävrörelsen sin kraft ur samma typ av föreställningar? Var ambitionen att distansera sig från det sena industrisamhällets alienation och utarmning genom en uppvärdering av det äldre industrisamhällets arbetare, arbetarkultur och fackliga verksamhet? Alzén ser en överensstämmelse med hembygdsrörelsens vurmande för bonden och hantverkaren. Tanken är förvisso inte ny, men inte desto mindre intressant och värd ytterligare diskussion och studier."

Så slutar Alzéns undersökning i en kritisk granskning av två skilda rörelser, vilka båda uppstod och utvecklades i två samhälleliga brytningsskeden. Den ena lämnade viktiga bidrag till den traditionella kulturarvsdiskursen, den andra bidrog till dess upplösning och det definitiva etable- randet av en modern diskurs där industrin godtogs som kultur. Båda rörelserna var demokratiska. Båda protesterade mot förhållanden i tiden och var en länk mellan två samhällssystem. Skillnaden var att medan hembygdsrörelsen drömde om det goda livet i det förflutna såg, enligt Alzén grävrörelsen mot den «ljusa framtiden». Påståendet är dock inte invändningsfritt. Det är troligt att båda rörelserna uppträdde som sköldar mot samtidens förändringar, och att båda ville föra bestämda värden in $\mathrm{i}$ framtiden.

\section{SAMMANFATTANDE OMDÖME}

Alzén har presterat en habil undersökning, som presenteras i välskriven och vacker bok. ${ }^{7}$ Hon har formulerat angelägna frågor, definierar sina begrepp och presenterat en rimlig tolkning av förloppet, med hämmande och pådrivande faktorer, viktiga aktörer och tankemönstrets successiva förändring. Även om hon själv inte använder ordet är det i mycket en aktörsstudie hon har genomfört. Studien kan också ses som en maktstudie, dvs hur olika aktörer agerar och vilka maktresurser de använder för att hävda sina intressen.

Fabriken som kulturarv är den första svenska doktorsavhandlingen med denna inriktning. Jag saknar ändock en forskningsöversikt. Det är brukligt i vetenskapliga sammanhang och viktig som avstämning. Vilka vetenskapliga referenspunkter finns i detta sammanhang? Även om det inte skulle föreligga några jämförbara svenska studier, finns kanske referenser inom angränsande fält vilka kan ha inspirerat (diskursanalyser är inte något helt nytt). Dessutom kan det finnas utländska undersökningar väl värda att lyfta fram. 
104 Alzén är nu inte helt ensam om att ha studerat Norrköpings omvandling. Eva Dahlström undersökte redan 1991 återanvändningen av byggnaderna i Norrköpings industriområde $\mathrm{i}$ en 60-poängs uppsats $\mathrm{i}$ konstvetenskap. Även hon beaktar grävrörelsen, Arbetets museum och händelserna i samhället på 1970- och 1980-talen. Dahlström urskiljer två linjer i synen på industrimiljöer, dels den «den traditionellt kulturhistoriska» och dels "den socialt politiska» aspekten. Alzén refererar till Dahlström på ett par ställen, men stannar med detta trots att det finns stor överensstämmelse i beskrivning och analys ${ }^{8}$.

Diskurser är inte helt lätta att använda $\mathrm{i}$ historisk forskning. Hur förändras diskurser och hur förhåller de sig till den sociala praktiken? En diskursanalys kräver en noggrann textläsning, med en analys av argument, aktörers agerande och språk, texters och bilders konstruktion. Hur konstrueras mening och sammanhang? En sådan ingående läsning gör inte Alzén. Hon urskiljer två åsiktslinjer, den traditionella och den moderna, vilket hon $\mathrm{i}$ och för sig bygger under. Däremellan finns en diskurs som hon benämner den «utvidgade" som i sin tur sönderfaller i en industrihistorisk och en arbetarhistorisk. Dessa tillsammans ger den nya moderna diskursen. Hur dessa huvud- och deldiskurser står till varandra, och till den sociala praktiken, förblir en aning oklart. Den moderna tycks växa fram både ur och vid sidan av den traditionella. Samtidigt förändras den traditionella mot en utvidgad, men lever samtidigt kvar parallellt med den nya?

Med sitt val av perspektiv väljer Alzén att skära bort det konkreta kulturvårdsarbetet på lokalplanet. Samtidigt framgår det av avhandlingen att diskursen i mycket formades av problem och konkreta händelser i Norrköping (kraftverket, Strykjärnet, nedläggningen av textilindustrin, Holmens pappersbruk etc). Min fråga blir därför om de erfarenheter som antikvarier, stadsplanerare, arkitekter, byggherrar, fastighetsägare m.fl. gjorde i vardagen på fältet (sociala praktiker) ändå inte bidrog till att förändra gällande tankemönster på lokalplanet? Var det överhuvudtaget möjligt att etablera och hävda den diskursen bland aktörerna om den inte hämtade stöd i och klarade provet vid en testning i den lokala "verkligheten".

Samtidigt är jag tveksam till om det är rimligt att ge grävrörelsen och Arbetets museum en så framträdande roll i sammanhanget? Vilka andra samtida förhållanden kan ha varit viktiga, som inte berörs, eller bara flyktigt berörs av Alzén?

Vilken betydelse bör rimligen tillmätas 1974 års kulturproposition, som Göran Rosander har rubricerat som «ett slags kulturens Saltsjöbadsavtal» som "måste anses ha påverkat tidsandan»?" Alzén nämner i och för sig den nya kulturpolitiken, men analyserar inte dess roll i sammanhanget. Vad säger att det inte var de åtta målen i 1974 års kulturpolitik som, tillsammans med politiska och ekonomiska händelser i samtiden, öppnade både för ett nytänkande bland antikvarier och gav kraft åt grävrörelsen?

Vad betydde den nya fysiska riksplaneringen, som integrerade kulturvården $\mathrm{i}$ samhällsplaneringen? Hur skall vi se på AMS och de medel som frigjordes för beredskapsarbeten redan omkring 1970 och som utökades under krisåren mot slutet av 1970-talet? Hur skall vi värdera betydelsen av andra samtida utredningar 
som öppnade för ett bredare synsätt inom kulturmiljövården: Kulturminnesvårdsutredningen (SOU 1972:45), Saneringsutredningen (SOU 1973:27), Bygglagsutredningen (SOU 1974:21), Byggnadsvårdsutredningen (SOU 1979:17)? Som läsare önskar man sig åtminstone en diskussion på denna punkt.

Hennes hypotes om grävrörelsens viktiga roll $\mathrm{i}$ sammanhanget borde ha byggts under med en inträngande skildring och analys av denna rörelse i Norrköping. Vilken omfattning hade den och hur arbetade man här för att bevara industrilandskapet? Går det att belägga att de tongivande personerna och grupperna i staden påverkades av grävrörelsen och Arbetets museums tillskyndare? Tog de snarare intryck av andra beslut, rörelser och händelser, lokalt och nationellt?

De hämmande faktorer som Alzén lyfter fram i inledningskapitlet förefaller helt rimliga och jag har inget att invända mot dem. Min fråga är av mer filosofisk karaktär. Kan man verkligen prata om hämmande faktorer i en tid då driften pågick i fabrikerna och idén att bevara industribyggnader och andra industriminnen inte, eller knappast, alls, var uttänkt. Efteråt kan vi formulera ett bevarandeperspektiv, men var det över huvudtaget möjligt dessförinnan? När är det överhuvudtaget möjligt att förankra en idé om bevarande? Om detta inte var möjligt kan man då tala om hämmande faktorer? Hämmande var snarare en fråga om något otänkbart, utanför diskursen?

Bland de hämmande faktorerna ingår ekonomiska svårigheter att bevara stora industrianläggningar. Men var det inte just ekonomiska förhållanden som räddade Industrilandskapet från rivning? Det var dyrt att riva byggnaderna, ekonomi saknades för nybyggnation och lokalerna kunde hyras ut till småfirmor och föreningar. Ekonomiska förhållanden gynnade industrilandskapets etablering $\mathrm{i}$ det första skedet?

Trots en intressant undersökning kan sålunda en rad.invändningar riktas mot Alzéns perspektiv och vad hon väljer att studera och inte studera, liksom hennes sätt att kartlägga och tolka perspektivskiftet. Det finns också en formella brister (noter och källförteckning, bildtexter etc). Sammantaget är det ändå en stimulerande och viktig bok som Alzén har skrivit, och vi kan hoppas att forskningen om kulturarv och industrimiljöer nu kommer igång på allvar. Det finns åtskilliga studier som väntar på att bli gjorda. När nu exemplet Norrköping föreligger, öppnas möjligheterna för komparation och en utveckling av teorier och metoder för studier av «fabriken som kulturarv».

\section{NOTER}

1. Annika Alzén, Fabriken som kulturarv. Frågan om industrilandskapets bevarande i Norrköping 1950-1985. Symposium 1996. 156 sidor (stort format).Se också J. Anshelm(red), Modernisering och kulturarv. Essäer och uppsatser. Stockholm 1993.

2. Det "etablerade kulturarvet" definierar Alzén som det kulturarv som bevaras av institutioner, dvs museer och andra kulturvårdande myndigheter. Hon exkluderar följaktligen privata samlingar. Se s. 16.

3. Industriarkeologins förändring berörs dock knappast alls av Alzén. Jämför med Marie Nisser, "Industriminnen under hundra år", i Museet som makt och motstånd. Festskrift till Erik Hofrén, 10 
106 april 1996, s. 78. Arbetets museums vänner 1996.

4. För en beskrivning och analys av grävrörelsen, samt framtidsmöjligheter, se M. Isacson, «Varför har vi ingen grävrörelse i slutet av 1990-talet». Tiden 11997.

5. Ferdinand Tönnies och Johan Asplunds idealtyper. Gemeinschaft står för det rurala, det naturligt framväxta, samhället där de sociala relationerna är täta. Gesellschaft är motsatsen, dvs det urbana industrisamhället där nyttan styr och människor lever samman utan släktband och nära relationer. Se Alzén s. 117 och där anförd litteratur.

6. Se t.ex. M. Isacson, «Arbetslivsforskaren i det offentliga samtalet». Teknik och kultur 3-4 1992.

7. Det brister dock i användningen av referenser och i relationen mellan noter och käll- och litteraturförteckningen, se. t.ex. not 7 (ej titel och ort som hon f.ö. har), not 11, 12, 34 (förlagsort?), not 37 och 38 (ibid!, hänvisar till vad?), not 107 (sida? Texten sidan $32 \mathrm{om}$ betongfundament stämmer ej heller med Nisser 1976) not 128 och 132 (inkonsekvens), not 223,227, 327, mfl (vilka arkiv avses?, not 545 och 546 (var i källförteckningen?).

8. Eva Dahlström, Industrilandskapet i Norrköping: Ett exempel på de sista decenniernas uppvärdering av industrimiljör. Uppsats $60 \mathrm{p}$ i konstvetenskap, Uppsala universitet 1991.

9. Göran Rosander, «Museerna och tidsandans förändring", s. 19. I: Museerna som makt och motstaind (1996).

\section{SUMMARY}

A new field of research

A doctoral thesis has recently been presented at the University of Linköping by Annika Alzén which deals with the preservation of the old industrial area in the heart of Norrköping - once called Sweden's Manchester because of its flourishing textile industry.

The article summarizes the book and its analysis of the reorientation of official antiquarian attitudes in the 1970 s which this preservation project represents. It tries to trace the origin of the new preservation policy and points to English industrial archæology as a source of inspiration. The historical interest in disappearing industrial techniques, buildings and working environments aroused by the closure of many industries and a painful change in conditions on the labour market is another important incentive. The parallel to what happened at the turn of the century as a consequence of the changes in agriculture and the decline of rural communities is discussed. The dissertation undoubtedly opens up a new field of research and it is hoped that it will be further explored - perhaps within the research programme for 'Modernization and cultural heritage' at the University of Linköping.

Maths Isacson är professor i ekonomisk historia vid Uppsala universitet.

Adr: Ekonomisk-historiska institutionen, Box 513 , S-751 20 Uppsala

Fax +46-18 181223 